\title{
Gene encoding prolactin in cinnamon clownfish Amphiprion melanopus and its expression upon acclimation to low salinities
}

\author{
Gyeong Eon Noh', Sum Rho², Yong Jin Chang ${ }^{1}$, Byung Hwa Min ${ }^{3}$ and Jong-Myoung Kim ${ }^{\text {1* }}$
}

\begin{abstract}
Background: Prolactin (PRL) is a key hormone for osmoregulation in fish. Levels of PRL in the pituitary gland and plasma ion composition of clownfish seem to change to regulate their hydromineral balance during adaptation to waters of different salinities. In order to understand osmoregulatory mechanism and its association with growth performance and PRL in fish, the gene encoding PRL and its expression level in cinnamon clownfish Amphiprion melanopus upon acclimation to low salinity was analyzed.

Results: The PRL gene of A. melanopus encoded a protein of 212 amino acid residues comprised of a putative signal peptide of 24 amino acids and a mature protein of 188 amino acids. Analysis of growth performance under different salinities of $34,25,15$, and 10 ppt indicated that cinnamon clownfish could survive under salinities as low as 10 ppt. A higher rate of growth was observed at the lower salinities as compared to that of 34 ppt. Upon shifting the salinity of the surrounding water from $34 \mathrm{ppt}$ to $15 \mathrm{ppt}$, the level of the PRL transcripts gradually increased to reach the peak level until $24 \mathrm{~h}$ of acclimation at $15 \mathrm{ppt}$, but decreased back as adaptation continued to $144 \mathrm{~h}$. In contrast, levels of plasma $\mathrm{Na}^{+}, \mathrm{Cl}^{-}$, and osmolality decreased the initial stage (4-8 h) of acclimation at $15 \mathrm{pt}$ but increased back as adaptation continued till $144 \mathrm{~h}$.

Conclusion: Cinnamon clownfish could survive under salinities as low as 10 ppt. Upon shifting the salinity of the surrounding water from $34 \mathrm{ppt}$ to $15 \mathrm{ppt}$, the level of the PRL transcripts gradually increased during the initial stage of acclimation but decreased back to the normal level as adaptation continued. An opposite pattern of changes decrease at the beginning followed by an increase - in the levels of plasma $\mathrm{Na}^{+}, \mathrm{Cl}^{-}$, and osmolality was found upon acclimation to low salinity. The results suggest an involvement of PRL in the processes of osmoregulation and homeostasis in A. melanopus.
\end{abstract}

Keywords: Osmoregulation, Prolactin; Osmoregulation, Clownfish; Amphiprion melanopus

\section{Background}

The marine ornamental industry has been continuously widening its proportion in the multi-billion dollar ornamental fish industry, including the associated equipments and accessories in recent years [1]. However, growth of the marine ornamental fish trade has been hindered by problems such as capture techniques damaging the ecosystem, over-exploitation, and high levels of mortality caused by inadequate handling and transport of sensitive living organisms [2]. One way to reduce the pressure on

\footnotetext{
* Correspondence: jongkim@pknu.ac.kr

'Department of Fishery Biology, Pukyong National University, Busan 608-737, South Korea

Full list of author information is available at the end of the article
}

the ecosystem but to meet the increasing demands for marine ornamentals is to improve the efficiency of the capture as well as the culture system for desirable marine organisms. Therefore, it is necessary to understand the physiology of the target organisms. In teleosts, development and growth are known to be under the control of environmental factors such as temperature, salinity, and photoperiod [3]. There have been many reports about the effects of water salinity on the development and growth of fish [4]. Several advantages have been recognized for maintaining marine fish at lower salinities, probably by reducing osmotic stress and diseases associated with parasites which thrive higher salinities and by reducing the cost for maintaining the fish in a hatchery using artificial 
saltwater [5]. In addition, some euryhaline teleosts showed a better growth rate at intermediate salinity conditions, i.e. in brackish water of 8-20 ppt [3].

Cinnamon clownfish A. melanopus is one of the most popular species in marine ornamental trade. Clownfishes are protandric hermaphrodites, indicating that males change their sex to females. Most clownfish live in groups consisting of a female, a male, and several subadults and/or juveniles. The female is the most dominant member of the group, and her constant maintenance of the pecking order prevents the male from changing sex. Developments of mature sex organs as well as the growths of subadults are repressed by the presence of the adult pair. By maintaining a size disparity between members in the pecking order, lower-ranking clownfishes are able to reduce the conflict and are less likely to be evicted from the host anemone [6,7]. In addition, cinnamon clownfish are known to inhabit the regions of the lagoon and outer reef environments in the Great Barrier Reef of Australia, Indonesia, and the Solomon Islands, and in the tropical regions where freshwater input is pervasive throughout the wet tropics, at least in a seasonal context, from direct rainfall and river runoff. This indicates that clownfish have an ability to adapt to water with low salinity and are of interest for studying the physiology associated with social hierarchy and the osmoregulatory mechanism of fish.

Prolactin (PRL) is a key hormone important for osmoregulation in fish by regulating the entry of ions and water uptake. In general, levels of PRLs in the pituitary gland and plasma ion composition of fish seem to be increased during adaptation to freshwater for regulating the hydromineral balance by decreasing water uptake and increasing ion retention [8]. Since most of the low salinity adaptation studies in marine fish have been carried out with a rather large edible fish, it is necessary to examine the role of PRL in marine ornamental fish and the optimum salinity for its growth. For this, the gene encoding PRL and its transcript level, together with the growth performance of $A$. melanopus, were analyzed upon its adaptation to low salinity.

\section{Results}

\section{Gene structure and amino acid sequence of PRL}

The gene encoding PRL of cinnamon clownfish was obtained by PCR amplification using genomic DNAs and cDNA templates and primers as described (Table 1, Figure 1). The PRL gene consists of five exons (639 bp) separated by four introns $(1,438 \mathrm{bp})$ and the sizes of the five exons were 43, 113, 108, 183, and $192 \mathrm{bp}$, respectively (Figure 2). An ORF encoded a protein of 212 aa residues comprised of a putative signal peptide of 24 aa and a mature protein of 188 aa. The sizes of the four introns were 784, 241, 320, and $93 \mathrm{bp}$, respectively. All
Table 1 Primers used for PCR amplification of prolactin genes

\begin{tabular}{ll}
\hline Primers & Sequences $\left(\mathbf{5}^{\prime} \rightarrow \mathbf{3}^{\prime}\right)$ \\
\hline Deg-F & CCCTCCATGTGCCACACCTCC \\
Deg-R & AGGACTTTCAGGAAGCTGTCAAT \\
DW-F1 & GAGCTGCAGGAGCACTCCAAGAC \\
DW-F2 & CTCGGCCAGGACAAGATCTCCAA \\
DW-F3 & TCCTGCTGTCCTGCTTTCGCCG \\
DW-R1 & GTCTTGGAGTGCTCCTGCAGCTC \\
DW-R2 & TGACACTTGCAGAGCTTGTCCTTGTC \\
DW-R3 & CTTGTCATTGGGCGTCTGCAGAG \\
DW-R4 & CTGATGGGAACAGCTTTACACGCTGC \\
PRLF & ATGGCTCAGAGAAGAACCAATGGAAGC \\
PRLR & TTAGCACATCTCAGGCTGCATCTTGC
\end{tabular}

Deg: degenerate primer; DW: DNA walking; F: forward; PRL: prolactin; $\mathrm{R}$ : reverse.

the sequences found at the borders of introns contain consensus GT and AG splicing signals, and a TATA box (TATAAAA) was found at position -91. The PRL gene sequence was registered in the GenBank with an accession number HQ441171.

\section{Alignment of amino acid sequence and phylogenetic analysis}

Amino acid sequence comparison of $A$. melanopus PRL with those of other teleosts (Figure 3) using ClustalW [9] indicated aa identities of $83 \%$ with Epinephelus coioides (Accession No. AAO11695), 79\% with Acanthopagrus schlegeli (AAX21764), 78\% with Pagrus major (BAE43854), Rhabdosargus sarba (ABB17072) and Sparus aurata (AAC26852), 72\% with Takifugu rubripes (NP_001072092), 69\% with Oncorhynchus keta (CAA45407), 59\% with Danio rerio (NP_852102), and 58\% with Anguilla japonica (AAO17792). Cinnamon clownfish PRL contains four cysteine residues in the loci conserved in the PRLs of other teleosts. A phylogenetic tree also indicated a similarity between cinnamon clownfish and other teleost but a broad distinction from non-teleost PRLs (Figure 4).

\section{Growth of cinnamon clownfish reared under different salinity conditions}

Survival rates and the growth performance of A. melanopus were tested under different salinities. The survival rates of cinnamon clown fish grown under salinities of $34,25,15$, and 10 ppt were $86.7,58.8,43.8$, and $52.9 \%$, respectively, although the values seemed to be influenced by the attacking behavior of the dominant clownfish. Effects of salinity on growth were analyzed by the total length (TL), body height $(\mathrm{BH})$, and body weight (BW) of two dominant fishes with larger sizes, as the 


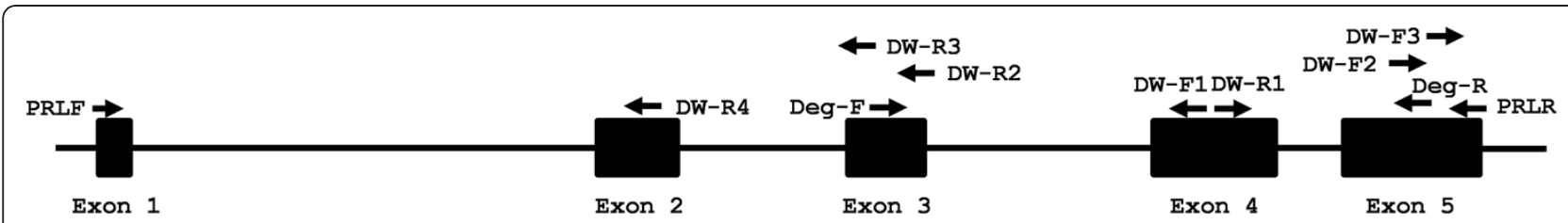

Figure 1 Structure of gene encoding PRL of cinnamon clownfish $\boldsymbol{A}$. melanopus. Positions corresponding to the primers used for PCR amplification are presented by arrows. PCR primers Deg-F and Deg-R were designed from the conserved regions of prolactins reported from other species in Genbank. DW-F and DW-R indicate primers used for DNA walking to obtain a full-length prolactin gene. Exons are represented by dark boxes and introns are represented by lines.

attacking behavior in the group might have had a greater influence on the growth of the smaller fish. The result showed a significantly higher TL and BW of clownfish reared at $25 \mathrm{ppt}$ as compared to those grown at $34 \mathrm{ppt}$ for 90 days (Figure 5). Clownfish groups acclimated at lower salinities of $15 \mathrm{ppt}$ and $10 \mathrm{ppt}$ also showed a higher BW as compared to that of $34 \mathrm{ppt}$.

\section{Expression of PRL in cinnamon clownfish upon acclimation to low salinity}

In order to analyze the level of PRL expression in cinnamon clownfish, RNAs were isolated from the pituitary glands of the fish reared in water where the salinity was shifted from $34 \mathrm{ppt}$ to $15 \mathrm{ppt}$. Fish were collected at 0, $4,8,24,48$, and $144 \mathrm{~h}$ of acclimation at $15 \mathrm{ppt}$ and subject to RNA isolation followed by a PRL transcript analysis using RT-PCR (Figure 6). The result showed an increase in the PRL transcript reaching the highest level (almost 5-fold) at $24 \mathrm{~h}$ of acclimation at $15 \mathrm{ppt}$ followed by a decrease in the level, but it was still higher than that of $34 \mathrm{ppt}$, as adaptation continued to $48 \mathrm{~h}$ and $144 \mathrm{~h}$.

\section{Plasma parameters}

The levels of $\mathrm{Na}^{+}, \mathrm{Cl}^{-}$, and osmolality were measured from the plasma of the fish exposed to 15 ppt. Levels of $\mathrm{Na}^{+}$in the plasma were $205 \pm 3.9,172 \pm 3.8,170 \pm 3.9$, and $175 \pm 3.3 \mathrm{mEq} / \mathrm{L}$, respectively, at $0,4,8$, and $24 \mathrm{~h}$ of acclimation (Table 2). The level was increased to $192 \pm 2.2$ $\mathrm{mEq} / \mathrm{L}$ as acclimation extended to $144 \mathrm{~h}$. The levels of $\mathrm{Cl}^{-}$were $189.1 \pm 1.0,159.6 \pm 3.6,156.2 \pm 4.2,158.2 \pm 2.2$, and $174.1 \pm 2.1 \mathrm{mEq} / \mathrm{L}$ at $0,4,8,24$, and $144 \mathrm{~h}$, respectively, of adaptation at 15 ppt. A similar tendency of plasma osmolality to decline in the initial stage but to recover its level as acclimation continued was also observed, as indicated by $379 \pm 1.0,312.5 \pm 5.5,313.0 \pm 3.0,331.5 \pm 2.5$, and $351.5 \pm 0.5 \mathrm{mOsm} / \mathrm{kg}$ of osmolalities at $0,4,8,24$, and $144 \mathrm{~h}$, respectively, of adaptations (Table 2).

\section{Discussion}

Clownfish have an ability to survive against a range of salinity changes as they are found in tropical habitats where freshwater input is pervasive in a seasonal context. The protandric hermaphrodites live as a social unit in which dominance affects the development and growth of the subordinate members. The study focused on the effects of salinity on the development and growth of the cinnamon clownfish, one of the most demanded species in the marine ornamental industry. Growth analysis of cinnamon clownfish at salinities of $34 \mathrm{ppt}, 25 \mathrm{ppt}, 15$ ppt, and $10 \mathrm{ppt}$ indicated that A. melanopus could survive at salinities as low as $10 \mathrm{ppt}$ over a period of 90 days. The result is similar to that of skunk clownfish $A$. akallopisos with high survival rates under the condition of salinities up to $53 \mathrm{ppt}$ and tolerance up to $6 \mathrm{ppt}$ of salinity [10]. Lower survival rates of $A$. melanopus at lower salinities were inconsistent with the previous studies examining the relationship between growth and salinity in juvenile black bream [11]. This might be due to their social organization in cinnamon clownfish because the growth parameters at lower salinities were higher than those at 34 ppt meaning a better growth, although we could not exclude the possibility of lower density effects on the growth. In addition, the results seemed to be affected, at least partly, by the social hierarchy system in cinnamon clownfish as it was often observed that the one (or two) dominant fish in the tank bit the smaller fish to death or chased them during the experiment. In fact, most of the dead fish were the small in size and were found to have serious wounds on their bodies and fins. Therefore, it is plausible to imagine that the stressful condition due to a decrease in salinity might contribute to more attacking behaviors leading to the decline of survival rate and growth [12].

According to Wilkerson [6], a typical clownfish social unit consists of a mature female, a mature male, and often with a few adolescents. A size-based, hierarchic dominance was noticed in common clownfish A. ocellaris: the female is the largest (rank 1) followed by the second largest male (rank 2) and the non-breeders get progressively smaller as their hierarchies are descended to ranks 3-6. Dominants seemed to gain no benefits from subordinates which are potential challengers for their position and occasionally evict or kill the subordinates of similar sizes. The small fish avoids the chases and challenges of larger members by signaling its acceptance of their positions in the social unit. An aggressor's 
cgtgtcaattataaaccttcgtgtttacattaatgcttttattcatcagtttaatcaagatcaggggagaacttttccatcca cacaactgggttatcagacctgccgctacatcctgttgcatccattcaaagccatgtttctcattataaaccggttccagaca attagtgcacgctgcataaccaaccgctggagctgagggactataaaatggagggaaaatggagcgagagaaagaaaagagg caaaactgagaaagagacagcaaaggaagagagagagagaagagagag ATG GCT CAG AGA AGA ACC AAT GGA AG

$$
\begin{array}{lllllllll}
\mathbf{M} & \mathbf{A} & \boldsymbol{Q} & \mathbf{R} & \mathbf{R} & \mathbf{T} & \mathbf{N} & \mathbf{G} & \mathbf{S}
\end{array}
$$

C AAA CTG CTC CTG ACA G gtgagatgaactcggcttattgatgtctttgggaggattttagaactgatttatacaatg

$$
\text { K L L L T }
$$

gaatctagtattttaatatacttttacaacatattaacctcgtgttgttctgcgggtcaaattgcctcgttttaaagtttga aaatgtggaaaaaatataagcttcaatttgttattttccatataaatttgatacattgccaaaaagaaatatctgtcat gattctctcatcttcataaaacaacacaatccaaactatttctgaatcagctcattcattattgtttagctaattagaaggt ggttgttattaaattgggaaggttatttagttgacattttagtgatatccagtcatttttattaataagtgattgttttaata gtaataatgatgtaatttgtaaagacatgatcataatgaacaaaaagttttgttgcttttaataaactgtatgcaagatgt atcccatggacttgaaaagtccctcaattatatattgacctgatatgtcatgttccattactgtcagattttcagaattatcaa tctgttggtgtcggagttatttaatgtcaaggcataatattcaataaaagaataaataaaatttgtatagcacctttata gatgagatgcagctcagagtattttatgtaaaactgcaatgcaaatgcagaaagtaagttcaatacaaaccaaagaacactaa actctacatttgaataaacagcaagacggtctttctgtgtgacttctctag TG TTG TAC GTG GTG GCA GCG TGT

$$
\begin{array}{lllllllllllll}
V & L & Y & V & V & A & A & C
\end{array}
$$

AAA GCT GTT CCC ATC AGT GAC CTC CTG GAC CGA GCC TCT CAG CGC TCT GAC AGA CTG CAC TCC 1214

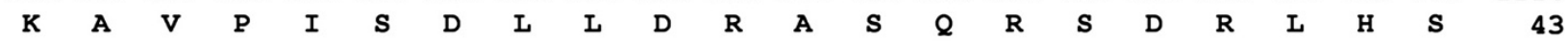
CTC AGC ACG ATG CTC ACC CGG GAG CTG gtcagtgtgtttgaacctcctctttctgctccctgactgacttcccat 1298 $\begin{array}{llllllllll}\mathbf{L} & \mathbf{S} & \mathbf{T} & \mathbf{M} & \mathbf{L} & \mathbf{T} & \mathbf{R} & \mathbf{E} & \mathbf{L}\end{array}$

gaacaacatcctgcacgagagcaacttctaaagataaaatattcagtcaggatttgcatgatttaaagcctgaacctttctggc 1382 agccactggttattattcatgtcctaaatcagcatgctgactgttgaagcttgcttcccgcatttgtcagtcaagtttttgat 1466 atatgtaatcatctgcctcctccag GAC TCT CAT TTC CCT CCG ATA GGC AGA ATG ATC ATG CCT CGC CC 1535

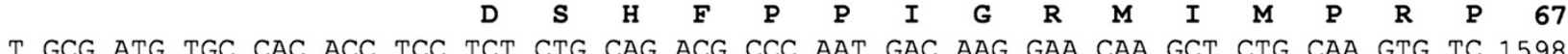
$\begin{array}{llllllllllllllllllllll}\mathbf{A} & \mathbf{M} & \mathrm{C} & \mathrm{H} & \mathrm{T} & \mathbf{S} & \mathbf{S} & \mathrm{L} & \mathbf{Q} & \mathbf{T} & \mathbf{P} & \mathbf{N} & \mathbf{D} & \mathbf{K} & \mathbf{E} & \mathbf{Q} & \mathbf{A} & \mathrm{L} & \mathbf{Q} & \mathbf{V} & \mathbf{S} & \mathbf{8 8}\end{array}$ A gtaagttagtctgaggctgaagtcaaacggctaaaaattgtgtctttttctaaacaattttcttgcatgtcgatggaaaac 1681 gtcaaggagaaatgtgggggagaattcgtgaggatgaaaggcaacagaggtgcaaagataaacaataaaaggacaggaaggat 1765 cataaatgagtcacatgttaaagcagctaaggaaggaagcactgaagcatcttttcttagcatttagagaaatatagcagctc 1849 gtatcaaagctgccactgagatattctggatcatttcactcagttatagtatttctgacccgtcctccag GAG TCA GAC C 1929

TG CTG TCT TTG GCT CGC TCC CTG CTC CGG GCC TGG GTG GAC CCC CTG CTG GTC CTG TCC TCC T 1992 $\begin{array}{lllllllllllllllllllllllll}\text { I } & \text { L } & \text { S } & \text { L } & \text { A } & \text { R } & \text { S } & \text { L } & \text { L } & \text { R } & \text { A } & \text { W } & \text { V } & \text { D } & \text { P } & \text { L } & \text { L } & \text { V } & \text { L } & \text { S } & \text { S } & 112\end{array}$ CT GCT AAC ACC CTG CCT CAC CCG GCC CAG AAC AGC ATC TCC AAC AAG ATC CAG GAG CTG CGG G 2055 $\begin{array}{llllllllllllllllllllll}\mathbf{S} & \mathbf{A} & \mathbf{N} & \mathbf{T} & \mathbf{L} & \mathbf{P} & \mathbf{H} & \mathbf{P} & \mathbf{A} & \mathbf{Q} & \mathbf{N} & \mathbf{S} & \mathbf{I} & \mathbf{S} & \mathbf{N} & \mathbf{K} & \mathbf{I} & \mathbf{Q} & \mathbf{E} & \mathbf{L} & \mathbf{R} & 133\end{array}$ AG CAC TCC AAG ACC CTG GGA GAC GGC CTG AAC ATA CTG TCT GGG AAG gtgtgcaagagtcgcactctt 2123 $\begin{array}{llllllllllllllll}\mathbf{E} & \mathbf{H} & \mathbf{S} & \mathbf{K} & \mathbf{T} & \mathbf{L} & \mathbf{G} & \mathbf{D} & \mathbf{G} & \mathbf{L} & \mathbf{N} & \mathbf{I} & \mathbf{L} & \mathbf{S} & \mathbf{G} & \mathbf{K}\end{array}$ 149 acattcatctaaatgtttaaatatgtgttaaaaccatcctttattccctaactccctgcgtctcctcccag ATG GGT CCG 2204 $\begin{array}{rrrr} & \text { M } & \text { P } & 152\end{array}$ GCT GCT CAG ACC ATG TCC CTG CTC CCC TAC AGA GGA GGC AAT GAT CTC GGC CAG GAC AAG ATC 2267 $\begin{array}{llllllllllllllllllllll}\text { A } & \text { A } & \mathbf{Q} & \text { T } & \text { M } & \text { S } & \text { L } & \text { L } & \text { P } & \text { Y } & \text { R } & \text { G } & \text { G } & \text { N } & \text { D } & \text { L } & \text { G } & \text { Q } & \text { D } & \text { K } & \text { I } & 173\end{array}$ TCC AAA CTG ATC AAC TTC CAG TTC CTG CTG TCC TGC TTT CGC CGG GAC TCC CAC AAG ATT GAC 2330 $\begin{array}{llllllllllllllllllllll}\mathbf{S} & \mathrm{K} & \mathrm{L} & \mathrm{I} & \mathbf{N} & \mathbf{F} & \mathbf{Q} & \mathbf{F} & \mathrm{L} & \mathrm{L} & \mathbf{S} & \mathbf{C} & \mathbf{F} & \mathbf{R} & \mathrm{R} & \mathrm{D} & \mathbf{S} & \mathrm{H} & \mathrm{K} & \mathrm{I} & \mathrm{D} & 194\end{array}$ AGC TTC CTG AAA GTC CTG CGC TGC CGG GCG GCA AAG ATG CAG CCT GAG ATG TGC TAA atggtgaa 2395

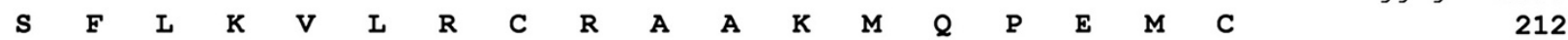
gcagccagcgtggctctgaggccetgctggatagg

2430

Figure 2 PRL gene of $\boldsymbol{A}$. melanopus and its coding sequence. Coding regions in the exons are shown as upper cases and non-coding regions are shown as lower cases. The corresponding amino acid sequences are indicated as bold characters. The boxed sequence represents a putative TATA box.

behavior and sound production involve chasing with chirping, jaw popping, ventral leaning, and dorsal leaning, following the response of an appeaser's behavior with rapid body quivering as the individual drifts upward with head up or down, clicking sounds, convulsive body shaking, quivering, and ventral leaning. All the behavioral patterns above were observed during our experiments with immature fish with size differences. It was also occasionally observed that the larger one would chase the smaller one and the latter would just swim away and fail to take position as a member. We conjectured that competition and even the attacking of smaller fish, which occurred during the process of stabilizing a hierarchy in the group under different salinities, might 


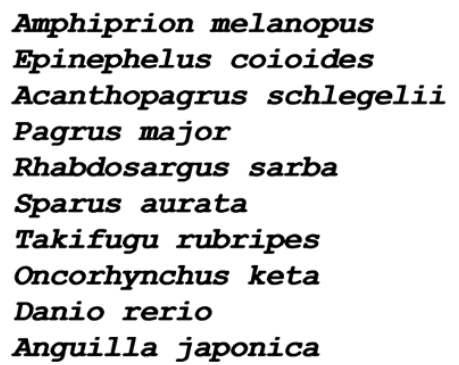

Amphiprion melanopus Epinephelus coioides Acanthopagrus schlegelii Pagrus major Rhabdosargus sarba Sparus aurata Takifugu rubripes Oncorhynchus keta Danio rerio Anguilla japonica

\section{Amphiprion melanopus Epinephelus coioides Acanthopagrus schlegelii Pagrus major Rhabdosargus sarba Sparus aurata Takifugu rubripes Oncorhynchus keta Danio rerio Anguilla japonica}

Amphiprion melanopus
Epinephelus coioides
Acanthopagrus schlegelii
Pagrus major
Rhabdosargus sarba
Sparus aurata
Takifugu rubripes
Oncorhynchus keta
Danio rerio
Anguilla japonica

MAQRRTNGSKLLLTVLYVVAACK-AVPISDLLDRASQRSDRLHSLSTMLTRELDSHFPPI 59 MAQRHSDGNKLLMTVLYMVAACS-AVPINDLLDRASQRSDRLHSLSTTLSHDLDFNFPPI 59 MARRETNGSKLFITVLCMVAACG-AVPISDLLDRASQRSDTLHSLSTTLTQDLNNHIPPV 59 MAHRGTNGSKIFITVLCIVAACS-AVPINDLLDRASQRSDTLHSLSTTLTQDLNNHVPPI 59 MAHRETNGSKLFI IVLCMVAACG-AVPINDLLDRASQRSDTLHSLSTTLTKDLSNHVPPV 59 MAHRETNGSKLFITVLCMVAACS-AVPINDLLDRASQRSDMLHSLSTTLTKDLSNHVPPV 59 MAHRKPGDILLLVTVLCMVATARGTVSTSDLLDRVSEHSDMIHSLSTILSQDLDSQLPPV 60 MARRSQGTKLHLAVL-CLVVSCH-AIGLSDLMERASQRSDKLHSLSTSLTKDLDSHFPPM 58 MAQGSR-QYFAVAILMCAFVSIN-GVGLNDLLDRASQLSDKLHYLSTSLTNDLDSHFPPI 58 MAQRFKGSNLFLTALLCLASQGH-AVGLGDMLERASQLSDKLHSLSTSLTNDLDTHFPPM 59

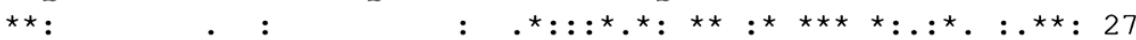

GRMIMPRPAMCHTSSLQTPNDKEQALQVSESDLLSLARSLLRAWVDPLLVLSSSANTLPH 119 GRMAMPRPSMCHTSSLQTPSDKEQALQVSESDLLSLARSLLQAWADPLVVLSTSANTLPH 119 GWMMMPRPSTCHTSSLQTPNDKEQALQLSESDLLSLARSLLQAWQDPLVVLSNSANSLVH 119 GWMMMPRPSLCHTSSLQTPNDKEQTLQLSESDLLSLARSLLQAWQDPLVDLSTSANSLLH 119 GWTVMPRPSLCHTSSLQTPNDKAQALQLSESDLMSLARSLLQAWRDPLADLSNSANSLLH 119 GWTMMPRPPLCHTSSLQTPNDKEQALQLSESDLMSLARSLLQAWQDPLVDLSNSANSLLH 119 GRMLLPRPSMCHTSSLQTPMDKEQALQISKSDLLSLARSLLHAWADPLLFLSTSAMTLPQ 120 GRVMMPRPSMCHTSSLQTPKDKEQALKVSENELISLARSLLLAWNDPLLLLSSEAPTLPH 118 GRGMMPRPSLCHTSSLQIPNDKDQAMKVPEDELLSLARSLLLAWSDPLALLSSEASSLAH 118 GKILMPRPSMCHTASLQTPHDKDQALRVPESELLSLARALLLSWNDPLLLLTSEAPTLSH 119

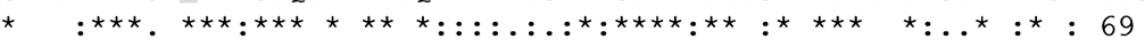

PAQNSISNKIQELQEHSKTLGDGLNILSGKMGPAAQTMSLLPYRGGNDLGQDKISKLINF 179 PAQSTISNKIQELQEHTKSLGDGLDILSGKMGPAAQLISSLPYRGGNDIGQDRISKLVNF 179 PSQSSISNKIRELQEHSKSLGDGLDILSGKMGPEAQAISSLPYRGSNDIGEDSISKLTNF 179 PSQTSISNKIRELQEHSKNLGDGLDILSGRMGPAAQAISSLPYRGGNDIGGDRISQLTNF 179 PSQSSISNKIRELQEHSKSLGDGLDILSGKMGPAAQTISSLPYRASNDIGEDNISKLTNF 179 PSQSSISNKIRELQEHSKSLGDGLDILSGKMGPAAQAISSLPYRGSNDIGEDNISKLTNF 179 LAQSSVSNKIQELKQHSQTLGDGLNILSDRMGQAAQAISSLPYSGGNDLGQDKISKLINL 180 PSNGDISSKIRELQDYSKSLGDGLDIMVNKMGPSSQYISSIPFKGG-DLGNDKTSRLINF 177 PERNTINSKTKELQDNINSLGAGLEHVVHKMGSSSDNLSTLPFNGN-NLGQDKTSRLVNF 177 PQNGVIYSKTRELQDQSNSLSSGLDRLIHKIGSSSKSLSPLPFQGG-DLGSDKNSRLINF 178

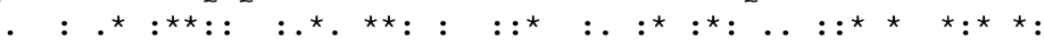

\begin{tabular}{|c|c|}
\hline SCFRRDSHKIDSFLKVLRCRAI & 212 \\
\hline SHKIDSFLKVLRCRAAKLRPEMC & 212 \\
\hline HFLLSCFRRDSHKIDSFLNVLRCRAAKLQPEMC & \\
\hline HFLLSCFRRDSHKIDSFLKVLRCRAAKVQPEMC & \\
\hline HFLLSCFRRDSHKIDSFLKVLRCRAAKMQPEMC & 213 \\
\hline HFLLSCFRRDSHKIDSFLKVLRCRAAKVQPEMC & 12 \\
\hline HFLLSCFRRDSHKIDSFLKVLRCRMANMVPEMC & \\
\hline HFLMSCFRRDSHKIDSFLKVLRCRATKIRPETC & \\
\hline HFLLSCFRRDSHKIDSFLKVLRCRAAKKRPDMC & \\
\hline YFLLSCFRRDSHKIDNFLKLLRCRAAKQ--DRC & \\
\hline
\end{tabular}

Figure 3 Multiple alignment of amino acid sequences of PRL in A. melanopus (AEB00558) as compared to those of other teleosts. Other prolactin sequences from Epinephelus coioides (AAO11695), Acanthopagrus schlegeli (AAX21764), Pagrus major (BAE43854), Rhabdosargus sarba (ABB17072), Sparus aurata (AAC26852), Takifugu rubripes (NP_001072092), Oncorhynchus keta (CAA45407), Danio rerio (NP_852102), and Anguilla japonica (AAO17792) were aligned by using ClustalW. The signal peptide sequence is marked by a box. Pairs of cysteine residues are shaded in grey. Identical amino acids among proteins are indicated by asterisks.

influence the survival rate. It will be interesting to examine the effect of low salinity on the growth of juvenile stages which showed schooling behavior without attacking behavior.

Analysis of growth performance at different salinities was carried out with two dominant fishes in the group to avoid the influence of dominance-related behavior, such as attacking the smaller fish. A higher rate of growth was observed in the groups reared at lower salinities as compared to those grown at $34 \mathrm{ppt}$. The result was consistent with other studies showing a better growth at intermediary salinity conditions, i.e. a brackish water of 8-20 ppt, in fish including O. niloticus, Mugil sp., Anarhichas lupus, S. aurata, and Hippoglossus 


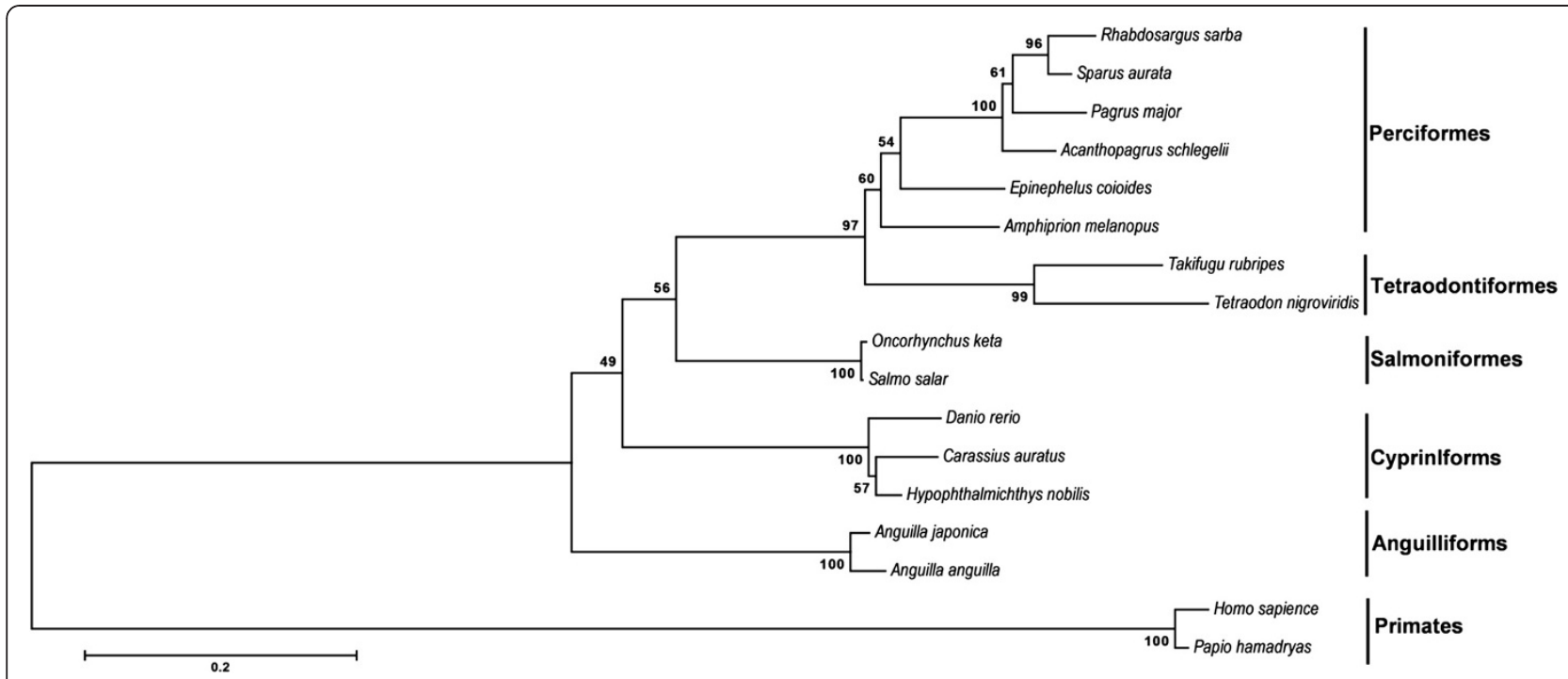

Figure 4 Construction of neighbor-joining tree based on amino acid sequences of PRLs. Bootstrap values are indicated for each node. Taxonomic groups are indicated on the right. Prolactin sequences from A. melanopus (AEB00558), Epinephelus coioides (AAO11695), Acanthopagrus schlegeli (AAX21764), Pagrus major (BAE43854), Rhabdosargus sarba (ABB17072), Sparus aurata (AAC26852), Takifugu rubripes (NP_001072092), Oncorhynchus keta (CAA45407), Danio rerio (NP_852102), Anguilla japonica (AAO17792), Tetraodon nigroviridis (AAR25696), Salmo salar (NP_001117140), Carassius auratus (AAT74865). Hypophthalmichthys nobilis (CAA43383), and Anguilla anguilla (CAA48902) were used for comparison. Prolactin sequences from Papio hamadryas (ADG56475) and Homo sapiens (AAH88370) were included as outgroups.

hippoglossus L [13-16]. According to Bœuf and Payan [3], this seemed to be attained by several factors including i) decline of energy cost: a drastic reduction of metabolic rate was found in rainbow trout $O$. mykiss at isotonic water [17] and the lowest gill $\mathrm{Na}^{+}, \mathrm{K}^{+}$-ATPase in juvenile turbot $S$. maximus correlate well with the best growth at intermediate salinity [18], ii) food intake and/or food conversion: better growth rates in cod Gadus morhua at lower salinity correlated well with an increase in food conversion efficiency [19] although more complex factors such as temperature and fish species might also be involved [16], and iii) hormones: thyroid hormone, growth hormone, and insulin-like growth factor were known to be involved in osmoregulation upon temporary salinity increase in salmonids [20]. Our results showed an increase in the level of PRL during an early stage of acclimation followed by a decrease as acclimation continued (see below). The results indicated that PRL may not be a major factor responsible for the higher growth of cinnamon clownfish in the intermediary salt condition during a long-term growth trial. At present, the plausible hypothesis suggests that the energy to retain osmotic pressure is saved in isotonic water and could be transferred for growth although clearer evidence is necessary.

PRL belongs to the same family as growth hormones, mammalian placental lactogen, and teleostean somatolactin and, in teleost, is known to act as a freshwateradapting hormone [8]. The structure of the PRL gene consisting of five exons and four introns was consistent with PRLs reported from other fish [21,22]. While nonteleosts such as Russian sturgeon Acipenser gueldenstaedtii and marbled lungfish Protopterus aethiopicus have mature PRLs of 204 aa and 200 aa, respectively [23,24], teleosts including European eel Anguila anguila, common carp Cyprinus carpio, and goldfish Carassius auratus, have PRLs of the sizes between 185 and 188 aa [25-28]. In addition, long (188 aa; PRL I) and short (177 aa; PRL II) forms of PRLs were reported in common carp and tilapia $[8,27,29]$. The PRL gene of $A$. melanopus obtained in this study encoded a prepeptide of 212 aa including a signal peptide of 24 aa and a mature protein of 188 aa, as similar to other piscine PRLs synthesized as prohormones with signal peptides of $23-24$ aa [8]. It also contains four cysteine residues (Figure 3) which might form two disulfide bridges in the mature protein as in other teleost PRLs [30], in contrast to nonteleost and mammalian PRLs having three disulfide bridges. Therefore, teleost PRLs can be characterized by lacking a disulfide bond in the N-terminal region and their lengths are shorter (by an absence of $12-14$ aa at the $\mathrm{N}$-terminus) than those of nonteleost and mammalian. Absence of the $\mathrm{N}$-terminal disulfide bridge might be important for osmoregulation as shown by the fact that injection of ovine PRL with a disrupted N-terminal disulfide bond increased the bladder potency in stickleback Gillichthys [31].

Salinity change in the surrounding waters cause an imbalance of ions and water in the fish [32]. Therefore, fish need to release ions and absorb water in seawater but 

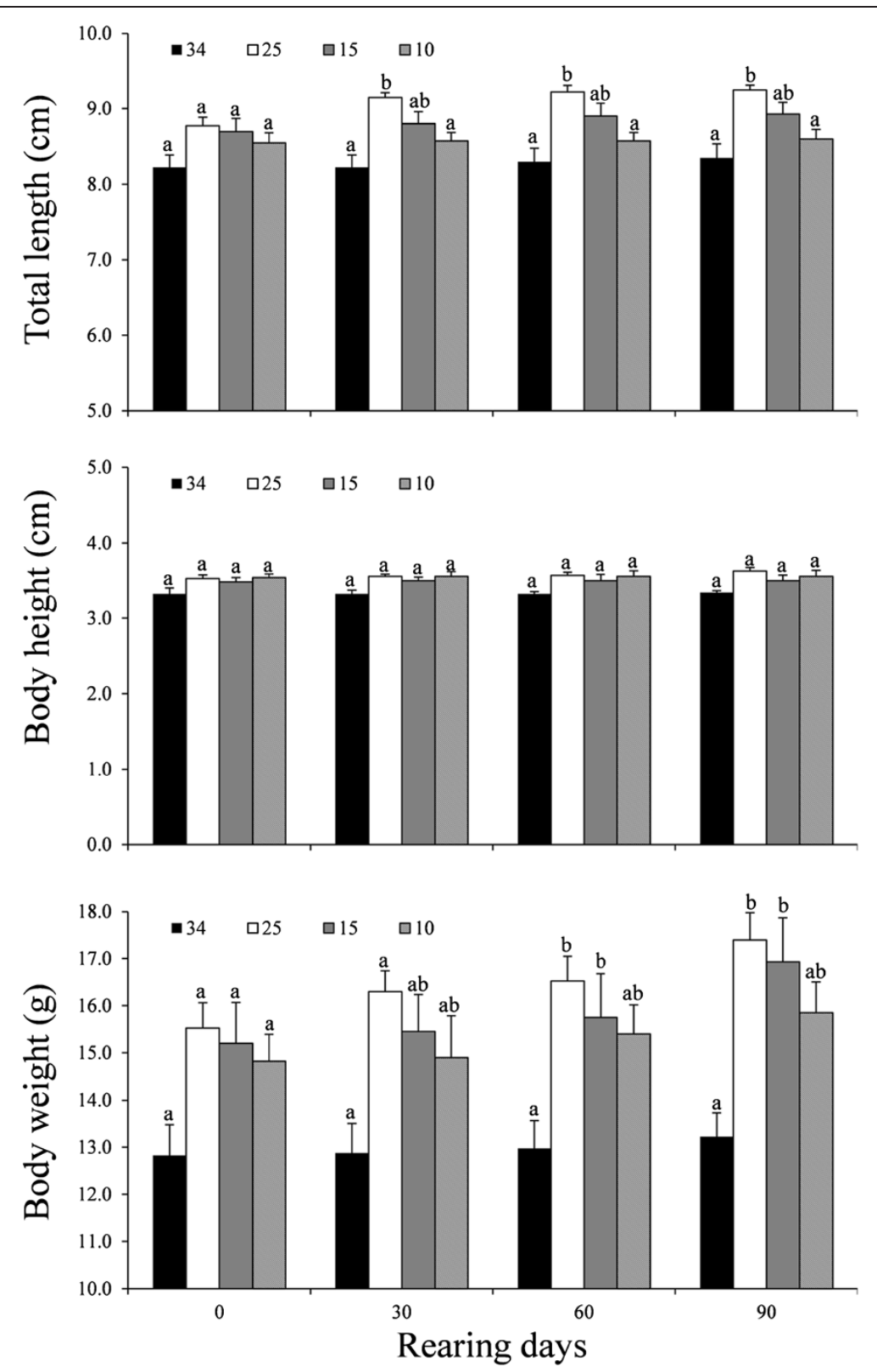

Figure 5 Effects of salinity on total length, body height, and body weight of the two dominant $A$. melanopus species in the group reared at different salinities for $\mathbf{9 0}$ days: $\mathbf{3 4}, \mathbf{2 5}, \mathbf{1 5}$, and 10 ppts. Values are means $\pm S D(n=4)$ and different letters indicate significant differences $(P<0.05)$.

absorb ions and release water in freshwater to maintain a constant level of osmolality. While A. melanopus could survive at salinities as low as $10 \mathrm{ppt}$, the fish consumed feed well at $15 \mathrm{ppt}$ as similar to that in $34 \mathrm{ppt}$ (Noh \& Kim, personal observation). Therefore, experiments for examining the correlation of PRL and osmoregulation were carried out at $15 \mathrm{ppt}$, which is similar to the salinity of the brackish water where cinnamon clownfish were found in nature. Upon shifting to $15 \mathrm{ppt}$, the level of PRL transcripts in the pituitary was increased until $24 \mathrm{~h}$ of adaptation and then declined slowly as acclimation extended to 48 and $144 \mathrm{~h}$. This was consistent with other studies showing an increase of the PRL transcript at lower salinity in pufferfish $T$. rubripes, black porgy A. schlegeli, gilthead sea bream $S$. auratus, and Mozambique tilapia $O$. mossambicus [30,33-35]. PRL levels in Atlantic salmon parr Salmo salar and ayu Plecoglossus altivelis were decreased upon transferring from freshwater to seawater [36,37]. It was also noticed that PRL influenced the retention and uptake of $\mathrm{Na}^{+}$in fish adapting to freshwater. An opposite pattern of changes, decrease at the beginning of salinity acclimation but increase to the normal level as adaptation 


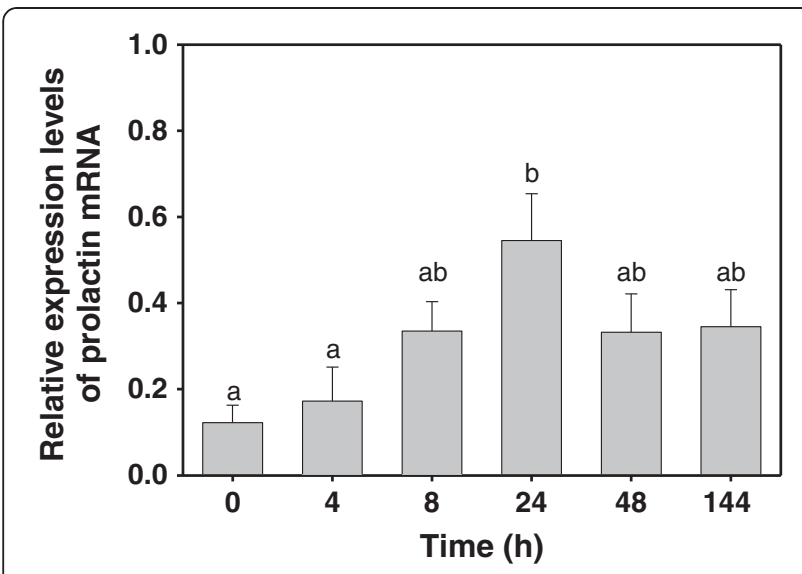

Figure 6 Analysis of PRL mRNA level in cinnamon clownfish $A$. melanopus upon exposure to 15 ppt. Total RNA $(0.5 \mu \mathrm{g})$ prepared from pituitary gland was used for generating CDNA by reverse transcription followed by PCR amplification using PRL-specific primers. Levels of $\beta$-actin mRNA were evaluated as a control. The expression level of each prolactin mRNA was normalized with respect to the level of $\beta$-actin transcript. Each value represents the mean $\pm S E(n=4)$ and the same letters indicate no significant difference $(P>0.05)$.

continued, was found in the plasma levels of $\mathrm{Na}^{+}, \mathrm{Cl}^{-}$, and osmolality. Correlation between the induction of the PRL transcript and osmolality changes upon exposure to low salinity indicates that PRL is involved during the early stage of adaptation to low salinity in cinnamon clownfish.

\section{Conclusions}

PRL gene in cinnamon clownfish consists of five exons encoding an ORF with a putative signal peptide of 24 aa and a mature protein of 188 aa as similar to those of euryhaline fish. PRL is involved in the initial stage of low salinity acclimation in cinnamon clownfish as shown by reaching a peak level at $24 \mathrm{~h}$ followed by a decrease in the level, indicating homeostasis. Cinnamon clownfish can be grown at salinities as low as 10 ppt. A better growth condition could be obtained at a lower salinity, providing the dominance-related killing of the smaller fish is prohibited. These are useful findings for marine ornamental fish aquaculture.

Table 2 Plasma $\mathrm{Na}^{+}, \mathrm{Cl}^{-}$ions, and osmolality in A. melanopus upon exposure to $15 \mathrm{ppt}$ water

\begin{tabular}{cccc}
\hline Time $(\mathrm{h})$ & $\mathbf{N a}^{+}(\mathbf{m E q} / \mathrm{L})$ & $\mathrm{Cl}^{-}(\mathrm{mEq} / \mathrm{L})$ & Osmolality $(\mathrm{mOsm} / \mathrm{kg})$ \\
\hline 0 & $205 \pm 3.9$ & $189.1 \pm 1.0$ & $379.0 \pm 1.0$ \\
4 & $172 \pm 3.8$ & $159.6 \pm 3.6$ & $312.5 \pm 5.5$ \\
8 & $170 \pm 3.9$ & $156.2 \pm 4.2$ & $313.0 \pm 3.0$ \\
24 & $175 \pm 3.3$ & $158.2 \pm 2.2$ & $331.5 \pm 2.5$ \\
144 & $192 \pm 2.2$ & $174.1 \pm 2.1$ & $351.5 \pm 0.5$ \\
\hline
\end{tabular}

Fish were transferred from $34 \mathrm{ppt}(0 \mathrm{~h})$ to $15 \mathrm{ppt}$ water. Values shown as mean \pm S.E. $(n=6)$ were measured from fish reared at $15 \mathrm{ppt}$ for the times indicated.

\section{Methods}

Animals and sampling procedure

Rearing experiments for PRL transcript analysis were carried out during June 2011. Fish $(\mathrm{n}=30,67.3 \pm 7.9 \mathrm{~mm}$ total length and $7.3 \pm 2.5$ g body weight) were divided into six groups and acclimated in a $120 \mathrm{~L}$ circular tank with a recirculatory system (34 ppt; 13 light: 11 dark cycle; $26.5 \pm 1.0^{\circ} \mathrm{C}$ ) for 5 days. Fish were fed Formula-one marine pellet (Ocean Nutrition, USA) twice a day. The salinity of the seawater (SW, 34 ppt) was lowered immediately by adding underground water until it reached 15 ppt. Five fish were collected with different intervals for $0,4,8,24,48$, and $144 \mathrm{~h}$, respectively, of acclimation. Fish were killed by spinal transection for the collection of the pituitary gland. Immediately after collection, the pituitary sample was frozen in liquid nitrogen and stored at $-80^{\circ} \mathrm{C}$ until RNA isolation for RT-PCR.

Growth of cinnamon clownfish $(\mathrm{n}=7 \sim 8)$ under different salinities was carried out in $120 \mathrm{~L}$ tanks $\left(26.5 \pm 1.0^{\circ} \mathrm{C}\right.$, $13 \mathrm{~h}$ light: $11 \mathrm{~h}$ dark) from July till the end of 2011. Fish were reared in the water salinities of $34,25,15$, and 10 ppts for 90 days and their survival rate, total length (TL), body height $(\mathrm{BH})$, and body weight $(\mathrm{BW})$ were estimated every 30 days.

\section{Cloning and characterization of the PRL gene in cinnamon clownfish}

Genomic DNA was extracted from the whole blood of clownfish using a AccuPrep ${ }^{\circledR}$ Genomic DNA extraction Kit (Bioneer Inc., Korea). PCR primers were designed from the conserved regions of PRLs reported in GenBank (Table 1). PCR was carried out in $20 \mu \mathrm{L}$ mixture containing genomic DNA $(0.05 \mu \mathrm{g} / \mu \mathrm{L})$, Deg F, and Deg R primers $(1 \mu \mathrm{M})$, and $1 \mathrm{x}$ HiQ-PCR Mix (GenoTech, Korea). Each reaction was carried out with an initial denaturation at $94^{\circ} \mathrm{C}$ for $4 \mathrm{~min}, 30$ cycles of reactions composed of denaturation at $94^{\circ} \mathrm{C}$ for $30 \mathrm{~s}$, annealing at $60^{\circ} \mathrm{C}$ for $30 \mathrm{~s}$, and extension at $72^{\circ} \mathrm{C}$ for $50 \mathrm{~s}$, followed by a final extension at $72^{\circ} \mathrm{C}$ for 5 min. DNA walking (Seegene, Korea) was performed according to the manufacturer's instructions (Figure 1) with DW-primers to obtain the regions corresponding to the $5^{\prime}$ - and 3 '-ends of the PRL gene. PCR products were purified using a gel extraction kit (NucleoGen, Korea) and cloned into Topcloner ${ }^{\mathrm{TM}} \mathrm{TA}$ kit (Enzynomics, Korea) according to the manufacturer's protocol.

\section{Expression of the PRL gene in cinnamon clownfish by reverse transcription (RT)-PCR}

Total RNA was extracted from pituitary glands $(n=4)$ using TRI Reagent (Sigma, USA). The total RNA sample was treated with DNase I for $30 \mathrm{~min}$ at $37^{\circ} \mathrm{C}$. Firststrand cDNA was synthesized in $20 \mu \mathrm{L}$ reaction containing $0.5 \mu \mathrm{g}$ total RNA and $0.5 \mu \mathrm{M} \mathrm{dT} \mathrm{T}_{15}$, ImProm- $\mathrm{II}^{\mathrm{TM}}$ Reverse Transcriptase (Promega, USA), $6 \mathrm{mM} \mathrm{MgCl}_{2}$, 
$0.5 \mathrm{mM}$ dNTPs, and 20 unit RNase Inhibitor (Enzynomics, Korea). RT-PCR was carried out with cDNA templates and PRLF/R primers at $94^{\circ} \mathrm{C}$ for $4 \mathrm{~min}$, and 20 cycles consisting of denaturation at $94^{\circ} \mathrm{C}$ for $30 \mathrm{~s}$, annealing at $60^{\circ} \mathrm{C}$ for $30 \mathrm{~s}$, and extension at $72^{\circ} \mathrm{C}$ for $50 \mathrm{~s}$, followed by a final polymerization at $72^{\circ} \mathrm{C}$ for 5 min. Levels of $\beta$-actin mRNA were evaluated to normalize the expression level of prolactin mRNA as described [38]. PCR products were resolved on agarose gel electrophoresis followed by staining with ethidium bromide and quantification by Gel Doc System/Station (BIORAD, USA).

\section{Plasma parameters analysis}

Blood was pooled from the caudal vasculature of five fish using a $1 \mathrm{~mL}$ syringe coated with heparin $(25,000$ $\mathrm{IU} / 5 \mathrm{~mL}$ ). Plasma samples were separated by centrifugation and stored at $-80^{\circ} \mathrm{C}$ until analysis. Levels of plasma $\mathrm{Na}^{+}$and $\mathrm{Cl}^{-}$ions were analyzed by using a Biochemistry Auto Analyzer (model 7180; Hitachi, Tokyo, Japan). Plasma osmolality was measured by using a Vapor Pressure Osmometer (Vapro 5520; Wescor Co., Logan, UT, USA).

\section{Sequence comparison}

The amino acid sequence of cinnamon clownfish PRL was aligned with the other PRL using ClustalW [9]. The phylogenetic tree was constructed by the neighborjoining method using MEGA v 5.0 with PRLs of various species selected from NCBI. The reliability of the phylogenetic tree was assessed by using a bootstrap with 1000 replicates with outgroups.

\section{Statistics}

Analysis was carried out with the SPSS statistical package (SPSS ver. 20, USA). One-way ANOVA followed by a post hoc multiple comparison test (Tukey's test) was used to compare differences in the groups. A nonparametric Kruskal-Wallis test followed by a Tukey's test using ranks was used for analysis of data collected from the two largest fish in the group and comparison of the PRL gene expression.

\section{Abbreviations}

PRL: Prolactin; aa: Amino acid.

\section{Competing interest}

The authors declare that they have no competing interests.

\section{Authors' contributions}

GE carried out gene cloning/growth analysis experiments and drafted the manuscript. SR provided clownfish and involved in growth experiment. YC contributed to design the experiment and data analysis. BM carried out osmolality analysis. JK contributed to experimental design, data analysis, and manuscript preparation. All authors read and approved the final manuscript.

Authors' information

GEN an expert in the field of fish physiology.
SR is a CEO of CCORA and an expert in the field of marine ornamental industry.

YJC and BHM are experts in the field of fish physiology.

JMK is a biochemist and molecular biologist.

\section{Acknowledgements}

The study about effect of salinity on growth of cinnamon clownfish was supported by the Korea Research Foundation Grant funded by the Korean Government (MOEHRD)" (KED-2006- 511-F00033). JK was supported by the Industrial Strategic technology development program (Project No: 1037416) funded by the MKE, Korea.

\section{Author details}

${ }^{1}$ Department of Fishery Biology, Pukyong National University, Busan 608-737, South Korea. ${ }^{2}$ COREA, Center of Ornamental Reefs and Aquariums, Jeju 690-974, South Korea. ${ }^{3}$ Aquaculture Industry Division, East Sea Fisheries Research Institute, Gangneung 210-861, South Korea.

Received: 10 July 2012 Accepted: 26 October 2012

Published: 1 January 2013

\section{References}

1. Moorhead JA, Zeng C: Development of captive breeding techniques for marine ornamental fish: a review. Rev Fish Sci 2000, 18:315-343.

2. Wabnitz C, Taylor M, Green E, Razak T: From Ocean to aquarium: The global trade in marine ornamental species. Cambridge, UK: UNEP-WCMC; 2003.

3. Bœuf G, Payan P: How should salinity influence fish growth? Comp Biochem Physiol C 2001, 130:411-423.

4. Specker JL, Schreiber AM, MCArdle ME, Poholek A, Henderson J, Bengtson DA: Metamorphosis in summer flounder: effects of acclimation to low and high salinities. Aquaculture 1999, 176:145-154.

5. Hoff FH: Conditioning, spawning and rearing of fish with emphasis on marine clownfish. Dade City, FL: Aquaculture Consultants Inc; 1996.

6. Wilkerson JD: Clownfish: A guide their captive care, breeding \& natural history. New Jersey: T.F.H. Publications Inc.; 2001.

7. Michael SW: Damselfishes \& Anemonefishes. New Jersey: T.F.H. Publications Inc:; 2008.

8. Manzon LA: The role of prolactin in fish osmoregulation: a review. Gen Comp Endocrinol 2002, 125(2):291-310.

9. Thompson JD, Higgins DG, Gibson TJ: CLUSTAL W: improving the sensitivity of progressive multiple sequence alignment through sequence weighting, position-specific gap penalties and weight matrix choice. Nucleic Acids Res 1994, 22(22):4673-4680.

10. Dhaneesh KV, Nanthini DK, Ajith Kumar TT, Balasubramanian T, Tissera K: Breeding, embryonic development and salinity tolerance of skunk clownfish Amphiprion akallopisos. J King Saud Uni Sci 2012, 24(3):201-209.

11. Partridge GJ, Jenkins Gl: The effect of salinity on growth and survival of juvenile black bream Acanthopagrus butcheri. Aquaculture 2002, 210:219-230.

12. Singley JA, Chavin W: Cortisol levels of normal goldfish Carassius auratus L., and response to osmotic change. Am Zool 1971, 11:653.

13. Peterson MS, Rakocinski SH, Comyns BH, Fulling GL: Influence of temperature and salinity on laboratory growth of juvenile Mugil sp. and implications to variable field growth. In Gulf Research Reports. vol. 11.; 1999:75.

14. Le François N, Lamarre S, Blier P: Tolerance, growth and haloplasticity of the Atlantic wolffish Anarhichas lupus exposed to various salinities. Aquaculture 2004, 236:659-675.

15. Laiz-Carrión R, Sangiao-Alvarellos S, Guzmán JM, Martín del Río MP, Soengas J, Mancera JM: Growth performance of gilthead sea bream Sparus aurata in different osmotic conditions: Implications for osmoregulation and energy metabolism. Aquaculture 2005, 250:849-861.

16. Imsland AK, Gústavsson A, Gunnarsson S, Foss A, Árnason J, Arnarson I, Jónsson AF, Smáradóttir $H$, Thorarensen $H$ : Effects of reduced salinities on growth, feed conversion efficiency and blood physiology of juvenile Altantic halibut Hippoglossus hippoglossus L. Aquaculture 2008, 274:254-259.

17. Rao G: Oxygen consumption of rainbow trout Salmo gairdneri in relation to activity and salinity. Can J Zool 1968, 46:781-786.

18. Imsland AK, Gunnarsson S, Foss A, Stefansson SO: Gill Na+, K+-ATPase activity, plasma chloride and osmolality in juvenile turbot Scophthalmus maximus reared at different temperatures and salinities. Aquaculture 2003, 218:671-683. 
19. Lambert $Y$, Dutil JD, Munro J: Effect of intermediate and low salinity conditions on growth rate and food conversion of Atlantic cod Gadus morhua. Can J Fish Aquat Sci 1994, 51:1569-1576.

20. Mancera JM, McCormick SD: Evidence for growth hormone/insulin-like growth factor I axis regulation of seawater acclimation in the euryhaline teleost Fundulus heteroclitus. Gen Comp Endocrinol 1998, 111(2):103-112.

21. Astola A, Ortiz M, Calduch-Giner JA, Perez-Sanchez J, Valdivia MM: Isolation of Sparus auratus prolactin gene and activity of the cis-acting regulatory elements. Gen Comp Endocrinol 2003, 134(1):57-61.

22. Boutet I, Lorin-Nebel C, De Lorgeril J, Guinand B: Molecular characterisation of prolactin and analysis of extrapituitary expression in the European sea bass Dicentrarchus labrax under various salinity conditions. Comp Biochem Physiol Part D Genomics Proteomics 2007, 2(1):74-83.

23. Noso T, Nicoll CS, Polenov AL, Kawauchi H: The primary structure of sturgeon prolactin: phylogenetic implication. Gen Comp Endocrinol 1993, 91(1):90-95.

24. Noso T, Nicoll CS, Kawauchi H: Lungfish prolactin exhibits close tetrapod relationships. Biochim Biophys Acta 1993, 1164(2):159-165.

25. Querat B, Cardinaud B, Hardy A, Vidal B, D'Angelo G: Sequence and regulation of European eel prolactin mRNA. Mol Cell Endocrinol 1994, 102(1-2):151-160.

26. Chao SC, Pan FM, Chang WC: Nucleotide sequence of carp prolactin cDNA. Nucleic Acids Res 1988, 16(19):9350.

27. Yamaguchi K, Specker JL, King DS, Yokoo Y, Nishioka RS, Hirano T, Bern HA: Complete amino acid sequences of a pair of fish (tilapia) prolactins, tPRL177 and tPRL188. J Biol Chem 1988, 263(19):9113-9121.

28. Chan YH, Cheng KW, Yu KL, Chan KM: Identification of two prolactin CDNA sequences from a goldfish pituitary cDNA library. Biochim Biophys Acta 1996, 1307(1):8-12.

29. Auperin B, Rentier-Delrue F, Martial JA, Prunet P: Evidence that two tilapia (Oreochromis niloticus) prolactins have different osmoregulatory functions during adaptation to a hyperosmotic environment. J Mol Endocrinol 1994, 12(1):13-24.

30. Lee KM, Kaneko T, Aida K: Prolactin and prolactin receptor expressions in a marine teleost, pufferfish Takifugu rubripes. Gen Comp Endocrinol 2006, 146(3):318-328.

31. Doneen BA, Bewley TA, Li CH: Studies on prolactin. Selective reduction of the disulfide bonds of the ovine hormone. Biochemistry 1979, 18 (22):4851-4860.

32. Mazeaud M, Mazeaud F, Donaldson EM: Primary and secondary effects if stress in fish: Some new data with a general review. Trans Ame Fish Soc $1977,106: 201-212$.

33. Laiz-Carrion R, Fuentes J, Redruello B, Guzman JM, Martin del Rio MP, Power $D$, Mancera JM: Expression of pituitary prolactin, growth hormone and somatolactin is modified in response to different stressors (salinity, crowding and food-deprivation) in gilthead sea bream Sparus auratus. Gen Comp Endocrinol 2009, 162(3):293-300.

34. Riley LG, Hirano T, Grau EG: Effects of transfer from seawater to fresh water on the growth hormone/insulin-like growth factor-I axis and prolactin in the Tilapia, Oreochromis mossambicus. Comp Biochem Physiol B Biochem Mol Biol 2003, 136(4):647-655.

35. Chang YJ, Min BH, Choi CY: Black porgy (Acanthopagrus schlegeli) prolactin CDNA sequence: mRNA expression and blood physiological responses during freshwater acclimation. Comp Biochem Physiol $B$ Biochem Mol Biol 2007, 147(1):122-128.

36. Agustsson $T$, Sundell $K$, Sakamoto $T$, Ando $M$, Th Bjornsson B: Pituitary gene expression of somatolactin, prolactin, and growth hormone during Atlantic salmon parr-smolt transformation. Aquaculture 2003, 222:229-238.

37. Yada T, Tsuruta T, Sakano H, Yamamoto S, Abe N, Takasawa T, Yogo S, Suzuki T, Iguchi K, Uchida K, et al: Changes in prolactin mRNA levels during downstream migration of the amphidromous teleost, ayu Plecoglossus altivelis. Gen Comp Endocrinol 2010, 167(2):261-267.

38. Noh GE, Lim HK, Kim JM: Characterization of genes encoding prolactin and prolactin receptors in starry flounder Platichthys stellatus and their expression upon acclimation to freshwater. Fish Physiol Biochem 2012, in press.

\section{doi:10.1186/2046-9063-9-1}

Cite this article as: Noh et al:: Gene encoding prolactin in cinnamon clownfish Amphiprion melanopus and its expression upon acclimation to low salinities. Aquatic Biosystems 2013 9:1.

\section{Submit your next manuscript to BioMed Central and take full advantage of:}

- Convenient online submission

- Thorough peer review

- No space constraints or color figure charges

- Immediate publication on acceptance

- Inclusion in PubMed, CAS, Scopus and Google Scholar

- Research which is freely available for redistribution

Submit your manuscript at www.biomedcentral.com/submit
C) BioMed Central 